\title{
Efektifitas Tanaman Refugia Border Crop terhadap Serangan Hama Plutella xylostella dan Crocidolomia binotalis pada Tanaman Kubis Bunga
}

\section{Effectiveness of Border Crop Refugia Against Plutella Xylostella and Crocidolomia binotalis on Flower Cabbage}

\author{
Ludviyatil Witri $\left.{ }^{1 *}\right) \&$ Hari Purnomo ${ }^{2)}$ \\ 1) Agrotechnology Study Program, Faculty of Agriculture, Universitas Jember, Jember Regency, Indonesia \\ 2) Soil Science Study Program, Faculty of Agriculture, Universitas Jember, Jember Regency, Indonesia \\ ${ }^{*}$ Corresponding author. ludviyatulwitri98@gmail.com
}

Received: February 1, 2021; Accepted: September 19, 2021; Published: October 31, 2021

\begin{abstract}
Pest attacks that become obstacles in cauliflower cultivation are Plutella xylostella and Crocidolomia binotalis, which can cause yield loss and crop failure. Efforts that can be used to reduce excessive use of pesticides are by controlling by the principles of integrated pest control by manipulating habitat using refugia plants grown as border crops. The plants used as refugia were $T$. subulata and $T$. erecta. The purpose of the study was to determine the effectiveness of refugia as a border crop against the intensity and attack of $P$. xylostella and $C$. binotalis pests. The design used was a Randomized Block Design (RBD) with four treatments and six replications. Observations were made eight times with an interval of one week. Parameters observed were pest population, attack intensity, and parasitization level. The population of $P$. xylostella and $C$. binotalis larvae was highest in the P0 (control) treatment. The lowest average $P$. xylostella and $C$. binotalis larvae population was in the $\mathrm{P} 3$ treatment $(T$. subulata $+T$. erecta). The highest percentage of damage intensity every week in the control treatment (P0). Treatment P3 (T. subulata + T. erecta) gave a significantly different effect compared to treatment P1 ( $T$. subulata) P2 ( $T$. erecta) and P0 (control). No parasitoid was found that attacks $P$. xylostella, Eriborus argenteopilosus is a parasitoid of $C$. binotalis with a parasitation rate of $54 \%$.
\end{abstract}

Keywords: biological control; cultivation; parasitization rate

Cite this as: Witri, L. \& Purnomo, H. (2021). Efektifitas tanaman refugia border crop terhadap serangan hama Plutella xylostella dan Crocidolomia binotalis pada tanaman kubis bunga. Agrosains : Jurnal Penelitian Agronomi, 23(2), 64-71. DOI: http://dx.doi.org/10.20961/agsjpa.v23i2.48224

\section{PENDAHULUAN}

Kubis bunga merupakan salah satu komoditas sayuran yang banyak dibudidayakan di Indonesia. Salah satu faktor yang dapat menyebabkan kerusakan pada tanaman kubis bunga yaitu serangan hama. Ulat daun kubis (Plutella xylostella) dan ulat krop (Crocidolomia binotalis) merupakan hama kubis bunga (Prabaningrum \& Moekasan, 2017). Larva P. xylostella memakan daun dan hanya menyisakan lapisan epidermis (Nazir, 2004). Gejala serangan C.binotalis lubang-lubang pada daun. Selain itu hama ini akan masuk ke dalam crop dan menghancurkan titik tumbuh (Erdiansyah et al., 2021). Serangan $C$. binotalis menyebabkan penurunan hasil $79,81 \%$ (Kristanto et al., 2013), sedangkan kehilangan hasil akibat serangan P. xylostella mencapai $58-100 \%$ (Li et al., 2021).

Penggunaan pestisida dengan bahan aktif organofosfat yang berlebihan dalam menanggulangi hama dapat menimbulkan dampak pencemaran baik air atau tanah selain itu menurunkan kondisi lingkungan karena berpengaruh terhadap musuh alami dipertanaman (Arif, 2015). Interaksi antara suatu organisme dengan lingkungannya akan menjadi tidak seimbang karena terdapat gangguan ekologi akibat penggunaan pestisida yang berlebihan. Pestisida yang berlebihan dalam penggunaannya juga berakibat terhadap kesehatan manusia. Kabupaten Bandung Barat petani yang menggunakan pestisida secara berlebihan berakibat pada kesehatannya. Hampir $75 \%$ dari 100 orang sampel tersebut mengalami dampak pusing. Penggunaan pestisida juga akan berdampak terhadap lingkungan (Rani et al., 2021). Penggunaan pestisida yang berlebihan di Desa Curut Semarang dengan bahan aktif yang digunakan dimenthorph, lamdacyhalothrin dan tiametocsan akan menyebabkan pencemaran baik tanah maupun air, selain itu akan menurunkan kondisi lingkungan karena berpengaruh terhadap musuh alami di sutau pertanaman (Yuliantari et al., 2015). Penggunaan pestisida di kalangan petani dapat menimbulkan masalah baru seperti membunuh organisme bukan sasaran (predator dan parasitoid) dan resistensi sehingga menyebabkan tingginya populasi hama dilapangan (Kamboj et al., 2017). Hama $P$. xylostella resisten terhadap beberapa jenis insektisida yang digunakan oleh petani kubis di Sulawesi Selatan (Purwaningsih et al., 2020). Hasil toksisitas diketahui hama P.xylostella resisten terhadap insektisida betacyfluthrin, lambda Cyhlothrinpermenthrin dan chlorantraniliprol. Petani kubis pada umumnya mengaplikasikan insektisida yang berlebihan, hal 
tersebut menyebabkan terjadinya resistensi hama P.xylostella terhadap insektisida tersebut. Salah satu contoh dampak negatif penggunaan isektisida dari golongan piretroid sintetik secara berlebihan untuk mengendalikan populasi $H$. armigera pada kapas di lamongan (Mulyadi et al., 2017). Penggunaan pestisida tersebut mengakibatkan peledakan populasi hama sekunder Bemisia sp. yang menyebabkan gagal panen.

Upaya yang dapat digunakan untuk mengurangi ketergantungan terhadap penggunaan pestisida yaitu dengan pengendalian yang sesuai dengan prinsip pengendalian hama secara terpadu. Pengendalian yang dapat dilakukan yaitu salah satunya dengan manipulasi habitat dengan menggunakan tanaman refugia. Salah satu upaya tersebut dengan menggunakanmanipulasi habitat menggunakan tanaman refugia. Penanaman tanaman refugia dapat menciptakan kestabilan ekosistem. Refugia akan menjadi sumber pakan dan sebagai tempat berlindung bagi musuh alami saat kondisi lingkungan menguntukan (Setyadjit \& Sukasih, 2015). Menanam tanaman pinggir di lahan budidaya maka akan dapat meningkatkan keanekaragaman hayati fungsional parasitoid dan predator dibandingkan dengan sistem penanaman tunggal (Amala \& Shivalingaswamy, 2018).

Refugia berupa kenikir dan kemangi yang ditanam dipertanaman sawi bersifat repellant bagi $P$. xylostella. Kedua tanaman tersebut mengeluarkan aroma yang tajam, selain itu juga mengandung bahan aktifflavonoida, polifenol, dan saponin sehingga dapat digunakan sebagai bahan insektisida (Mulyadi et al., 2017). Tanaman kemangi dan kenikir mengandung bahan aktif berupa flavonoida, polifenol dan saponin yang sering digunakan sebagai bahan insektisida dan didukung aroma yang dikeluarkan oleh kemangi. Tanaman refugia berupa bunga matahari dan tahi kotok yang ditanam secara-selang seling menyebabkan keragaman tanaman yang semakin banyak (Sepe \& Djafar, 2018). Penambahan tanaman refugia pada tanaman kubis secara tidak langsung memberikan pengaruh yang nyata terhadap populasi hama P.xylostella dan C.binotalis. Oleh karena itu, penelitian ini dilakukan untuk dapat mengetahui efektifitas tanaman refugia sebagai border cropterhadap serangan hama $P$. xylostella dan C.binotalis di pertanaman kubis bunga. Tujuan dari penelitian ini untuk mengetahui efektifitas tanaman refugia border crop terhadap populasi dan intensitas serangan hama $P$. xylostella dan C.binotalis di pertanaman kubis bunga serta ketertarikan musuh alami di pertanaman kubis bunga.

\section{BAHAN DAN METODE}

\section{Waktu dan Tempat Penelitian}

Penelitian dilaksanakan dilahan budidaya di Desa Burno Kecamatan Senduro Kabupaten Lumajang pada bulan Agustus - Oktober 2020. Identifikasi serangga dilaksanakan di Laboratorium Agroteknologi Fakultas Pertanian Universitas Jember.

\section{Rancangan Penelitian}

Penelitian menggunakan Rancangan Acak Kelompok (RAK) dengan menggunakan 4 perlakuan dan diulang sebanyak 6 kali sehingga terdapat 24 plot percobaan.Setiap plot berukuran 1,6 x 2,6 meter dengan jarak antar plot1 meter. Perlakuan terdiri dari P0 (kontrol), P1 (T.subulata), P2 (T.erecta), P3 ( $T$. subulata+ $T$. erecta).

\section{Prosedur Penelitian}

Pengolahan tanah dilakukan dengan menggunakan cangkul. T.erecta dan T.subulata ditanam 20-30 hari sebelum penanaman kubis bunga, tanaman refugia ditanam mengelilingi plot. Varietas yang digunakan yaitu Jayanti. penyemaian kubis bunga menggunakan media sosis. Pindah tanam dilakukan saat bibit berumur 25-30 hari. Penyulaman dilakukan paling lambat saat kubis bunga umur 2 minggu. Pemupukan dilakukan tiga kali yakni saat kubis bunga umur 7 hari setelah tanam (HST), 14 HST dan 21 HST. Pemupukan tanaman kubis bunga menggunakan pupuk ZA dan Urea. Pengamatan dilakukan setiap minggu, mulai 7 HST- sampai 8 HST. Penyiraman dilakukan setiap hari dan apabila musim hujan tidak diperlukan. Penyiangan dilakukan dengan mencabut gulma dengan sabit dan secara langsung menggunakan tangan. Musuh alami yang tertangkap di yellow pant trap dikumpulkan dalam botol yang berisi alkohol $70 \%$ dan kemudian dilakukan identifikasi menggunakan mikroskop berdasarkan ciri morfologi. Dalam satu lahan pertanaman kubis bunga terdapat 5 buah yellow pan trap yang dipasang secara diagonal. Rearing yang dilakukan yaitu meletakkan hama kedalam wadah yang berjumlah 2-3 larva per wadah dan diberi makanan ditutup dengan menggunakan kain kasa kemudian diganti makananya dan dibersihkan setiap 2 hari sekali. Larva akan diberikan makan sampai muncul parasitoidnya dan inangnya akan mati. Apabila larva tersebut menjadi ngegat jadi tidak terparasit.

\section{Variabel Pengamatan \\ Populasi Hama}

Pengamatan populasi hama $P$. xylostella dan $C$. binotalis yang menyerang tanaman kubis bunga dilakukansecara langsung. Populasi pada hama dihitung dengan menggunakan rumus sebagai berikut (Foster et al., 2021):

Populasi hama $=\frac{n}{N}$

Keterangan = $\mathrm{n}$ : jumlah hama yang didapat; $\mathrm{N}$ : Total hama pada tanaman sampel

\section{Intensitas Serangan}

Intensitas serangan P.xylostella dan $C$. binotalis dapat dihitung dengan rumus:

$\mathrm{P}=\sum \frac{n x v}{N x Z} \times 100 \%$

Keterangan:

$\mathrm{P}=$ tingkat kerusakan tanaman; $\mathrm{n}=$ jumlah rumpun yang memiliki nilai kerusakan (skor) yang sama; $v$ = nilai atau skoring kerusakan yang ditetapkan berdasarkan luas daun yang terserang; $Z$ = nilai kerusakan tertinggi; $N=$ jumlah daun yang diamati

Nilai skoring kerusakan yang berdasarkan luas daun yang terserang yaitu:

0 : tanaman sehat

1 : luas kerusakan daun $>0-25 \%$ (ringan)

2 : luas kerusakan daun $>26 \%-50 \%$ (sedang)

3 : luas kerusakan daun $>51 \%-75 \%$ (berat)

4 : luas kerusakan daun $>76 \%-100 \%$ (sangat berat) 


\section{Persentase Tingkat Parasitasi \\ Parasitoid D. Semiclausum}

Perhitungan tingkat parasitasi pada larva P.xylostella menggunakan rumus sebagai berikut (Hakiki et al., 2015):

Tingkat Parasitasi $=\frac{a}{b} \times 100 \%$

Keterangan:

a: Jumlah larva terparasit; b: jumlah larva keseluruhan

\section{Parasitoid E. argenteopilosus}

Persentase larva yang terparasit dihitung dengan menggunakan rumus (Gogi et al., 2021):

Persentase parasitoid

$=\frac{\text { larva terparasit }}{\text { larva yang didapatkan }} \times 100 \%$

\section{Identifikasi Serangga}

Identifikasi dilakukan di Laboratorium Agroteknologi Fakultas Pertanian Universitas Jember. Serangga yang didapatkan diidentifikasi sampai dengan tingkat famili menggunakan referensi Borror dan Ricard (A Field Guide to Insects).

\section{Analisis Data}

Data yang diperoleh pada variabel pengamatan dianalisis dengan analysis of variance (ANOVA) menggunakan software excel dan jika terdapat perbedaan yang nyata dilanjutkan dengan uji jarak berganda Duncan pada taraf $5 \%$.

\section{HASIL DAN PEMBAHASAN \\ Populasi Hama}

Berdasarkan Gambar 1 ada perbedaan populasi $P$. xylostella pada semua perlakuan. Jumlah populasi larva P. xylostella tertinggi yaitu pada perlakuan P0 (kontrol), sedangkan perlakuan terendah yaitu pada perlakuan $\mathrm{P} 3$ yaitu border crop dengan refugia $T$. subulata dan dan $T$. erecta. Perlakuan P0 (kontrol) populasi tertinggi yaitu pada minggu ke-8 sebesar 5 ekor/tanaman sedangkan pada minggu ke-2, 3, 4, 5, 6 dan 7 rata-rata populasi secara berturut-turut yaitu 2,$75 ; 3 ; 3,75 ; 4 ; 4,25$ dan 4 ekor/tanamaan. Perlakuan dengan tanaman refugia $\mathrm{P} 1$ ( $T$. subulata) populasi dari minggu ke 2 sampai 8 yaitu berturut-turut 1,$5 ; 1,75 ; 2,25 ; 2,5 ; 2,75 ; 2,5 ; 4$ ekor/tanaman. Populasi pada pada perlakuan P2 ( $T$. erecta) mengalami peningkatan dari minggu ke $2-8$ yaitu berturut-turut sebesar 0,$75 ; 1,75 ; 2,75 ; 3 ; 3,5 ; 3 ; 3,5$ ekor/tanaman. Perlakuan P3 kombinasi refugia ( $T$. subulata dan $T$. erecta) pada minggu ke1-8 bertututturut yaitu $0 ; 0,5 ; 1 ; 1,75 ; 2 ; 2,75 ; 2,5 ; 3,5$ Populasi larva $P$. xylostella di lahan pertanaman kubis bunga mengalami kenaikan dan penurunan pada setiap minggunya dapat disebabkan oleh beberapa faktor.

Manipulasi habitat dapat dilakukan dengan meningkatkan keragaman agroekosistem seperti menanam tanaman refugia yang dapat menarik dan sebagai tempat berlindung bagi musuh alami. Konsep manipulasi habitat bertujuan untuk melestarikan dan meningkatkan populasi musuh alami seperti predator dan parasitoid (Chandrasekara \& Kumar, 2016). Pengendalian biologis melalui musuh alami (predator dan parasitoid) merupakan komponen penting dalam mengendalikan hama, dengan menerapkan rekayasa ekologi dengan menanam tanam refugia akan dapat meningkatkan kotrol biologis karena menyediakan makanan seperti nektar dan serbuk sari (Badawy et al., 2019).

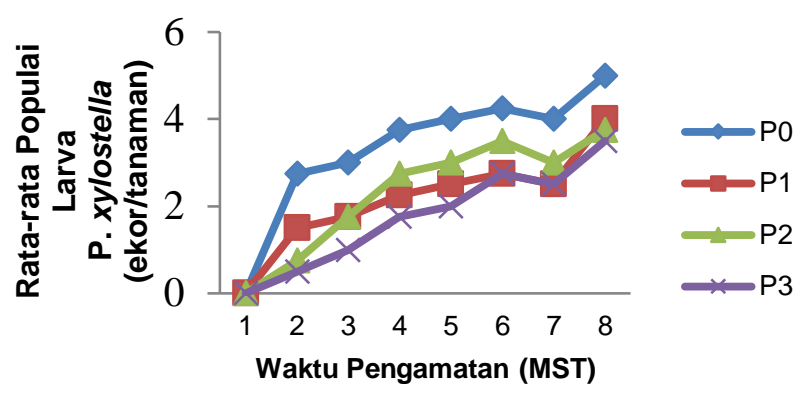

Gambar 1. Perbedaan populasi P. xylostella pada semua perlakuan

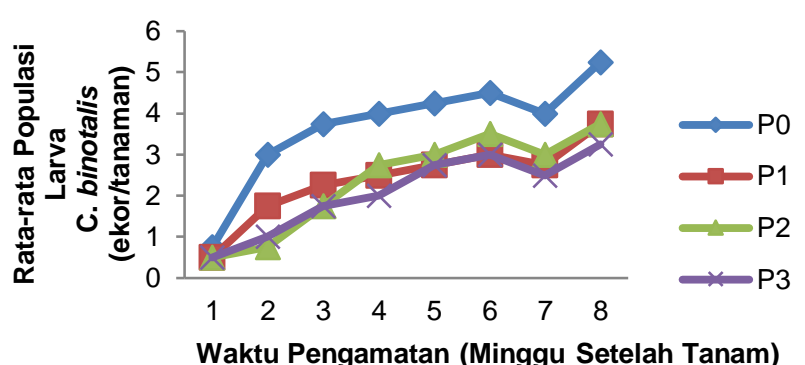

Gambar 2. Perbedaan Populasi C.binotalis pada semua perlakuan

Hasil pengujian sidik ragam anova memberikan hasil bahwa pada tanaman kubis bunga dengan "border crop" tanaman refugia efektif dibandingakan dengan kontrol. Perlakuan P3 (T.subulata + T.erecta) memberikan hasil berbeda nyata dibanding perlakuan lainnya (Tabel 1). Hal tersebut dibuktikan dengan hasil F-hitung yang lebih besar dari F-tabel $5 \%$. F hitung perlakuan populasi larva $P$. xylostella sebesar 4,423 sedangkan $\mathrm{F}$ tabel $5 \%$ 3,28 sedangkan untuk F-hitung perlakuan populasi $C$. binotalis sebesar 5,499 dan Ftabel $5 \%$ sebesar 3,28.

Tabel 1. Populasi P. xylostella dan C. binotalis pada kubis bunga

\begin{tabular}{lcc}
\hline \multirow{2}{*}{ Perlakuan } & \multicolumn{2}{c}{ Populasi Hama } \\
\cline { 2 - 3 } & P. xylostella & C. binotalis \\
\hline P0 : Kontrol & $8,568 \mathrm{c}$ & $8,159 \mathrm{~d}$ \\
P1: T.subulata & $6,683 \mathrm{ab}$ & $6,798 \mathrm{abc}$ \\
P2: T.erecta & $6,972 \mathrm{abc}$ & $6,646 \mathrm{ab}$ \\
P3: T.subulata + & & \\
T.erecta & $6,068 \mathrm{a}$ & $6,163 \mathrm{a}$ \\
\hline
\end{tabular}

Keterangan: angka yang diikuti notasi yang sama pada kolom yang sama tidak berbeda nyata pada uji Duncan $5 \%$

Populasi hama akan meningkat dengan penanaman secara monokultur karena ketersediaan inang yang disukai oleh hama. Faktor yang dapat mempengaruhi menigkatnya populasi $P$. xylostella dan dan $C$. Binotalis yaitu curah hujan, ketersediaan makanan, suhu dan kelembaban. Curah hujan yang tinggi dapat menekan penetasan telur ngengat $P$. xylostella (Heimoana et al., 2017). Suhu dan kondisi lingkungan akan mempengaruhi kepadatan populasi hama. Suhu dan kelembaban dapat mempengaruhi jumlah hama (Nusra et al., 2021). Suhu $26^{\circ} \mathrm{C}$ dan kelembaban $78 \%$ pada 
tanaman kubis umur \pm 35 HST dapat meningkatkan jumlah populasi hama. Berdasarkan penelitian yang sudah dilakukan suhu di lokasi penanaman tanaman kubis bunga yaitu $27^{\circ} \mathrm{C}$ dengan kelembaban $75 \%$. Saat kubis bunga umur 35 HST populasi hama meningkat karena ketersediaan makanan yang cukup dan dankrop kubis sudah mulai terbentuk. Populasi tertinggi ditunjukkan saat kubis bunga umur 35 HST, hal ini karena ketersediaan makanan yang cukup bagi hama sehingga populasi meningkat. Hama P. xylostella dan $C$. binotalis biasaya ditemukan pada tanaman yang sama namun terkadang tidak ditemukan pada tanaman yang sama hal tersebut karena perbedaan gejala serangan yang menyerang (Maina et al., 2020).

Populasi hama pada perlakuan refugia $T$. subulata dan $T$. erecta lebih rendah dibanding perlakuan lainnya. hal ini kemungkinan karena penggunaan tanaman $T$.

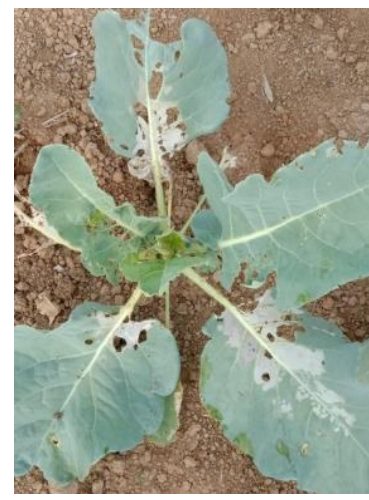

(a)

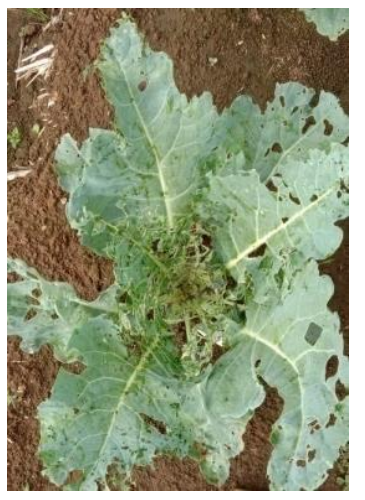

(b)

subulata dapat menarik (antraktan) dan T. erecta yang dapat menolak (repellant) karena memiliki aroma menyengat yang mungkin tidak disukai oleh serangga. Refugia $T$. subulata dan $T$. erecta mampu menjadi hostplant atau tempat berlindung bagi musuh alami seperti predator dan parasitoid sebelum musuh alami tersebut menemukan inangnya yaitu hama $P$. xylostella dan $C$. binotalis. $T$. erecta yang ditanam pada tanaman terong mampu mengurangi populasi hama penggerek pucuk (Leucinodes orbonalis). T. Erecta merupakan bunga yang mengandung volatile dan berfungsi sebagai repellent untuk penyerbuk (Badge et al., 2015). $T$. Erecta melindungi tanaman dengan cara menghalagi hama masuk ke tanaman utama dan menarik musuh alami (Calumpang \& Ohsawa, 2015; Zulfikar et al., 2019).

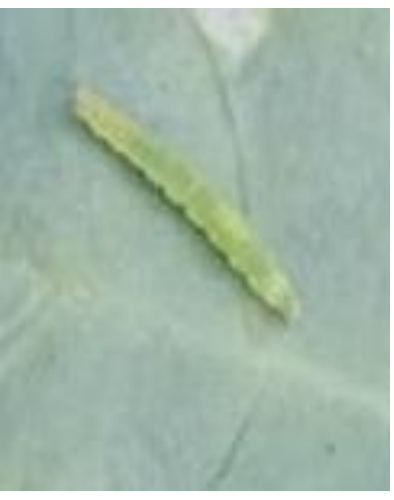

(c)

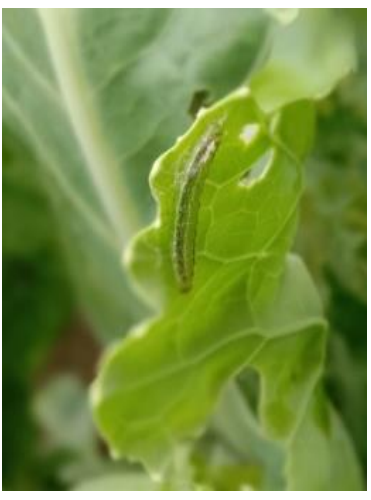

(d)

Gambar 3 (a) Gejala Serangan Hama P. xylostella (b) Gejala Serangan Hama C.binotalis (c) Hama P. xylostella (d) Hama C. binotalis

\section{Intensitas Serangan}

Pengamatan dilakukan dengan menghitung kerusakan daun pada tanaman yang terserang oleh hama $P$. xylostella dan $C$. binotalis.

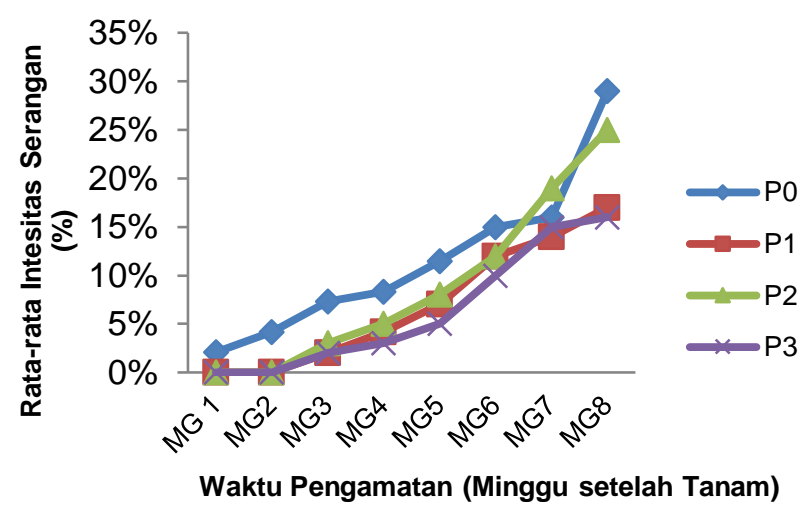

Gambar 4. Persentase intensitas kerusakan setiap minggu pada semua perlakuan(\%)

Berdasarkan Gambar 4, gejala serangan mulai terlihat pada minggu ke-1. Terdapat adanya perbedaan serangan antar pelakuan yaitu serangan yang paling berat adalah pada perlakuan PO (kontrol) sedangkan yang tidak terlalu berat pada perlakuan refugia P3 ( $T$. subulata dan $T$. erecta). Hal tersebut disebebakan karena pada perlakuan P3 terdapat tanaman refugia yang dapat meningkatkan musuh alami seperti predator dan parasitoid sehingga melindungi tanaman kubis bunga dari populasi hama $P$. xylostella dan $C$. binotalis. Perlakuan pertama yaitu kontrol (P0) Persentase tertinggi yaitu pada minggu ke-8 sampai mencapai kurang lebih $29 \%$, pada minggu ke 1-7 berturut-turut yaitu $2 \%, 4 \%, 7 \%, 8 \%, 11 \%, 15 \%$, dan $16 \%$.Perlakuan dengan tanaman refugia $T$. subulata $(\mathrm{P} 1)$ dari minggu ke 2-8 terus mengalami kenaikan. Minggu ke 1 dari perlakuan P1 tidak mengalami adanya gejala kerusakan, sedangkan dari minggu ke 2,3,4,5,6 dan 7 intensitas serangannya yaitu secara berturut-turut $1 \%$, $2 \%, 4 \%, 7 \%, 12 \%, 14 \%$ dan $17 \%$. Perlakuan dengan tanaman refugia T.erecta (P2) dari minggu ke-2 sampai minggu ke minggu ke-8 mengalami kenaikan yaitu secara berturut-turut dari minggu ke 3,4,5,6,7 yaitu $3 \%$, $5 \%, 8 \%, 12 \%, 19 \%$ dan $25 \%$ sedangkan untuk minggu ke 1 dan 2 tidak mengalami intensitas kerusakan. Perlakuan dengan kombinasi tanaman refugia $T$. Subulata dan $T$. erecta) pada minggu ke ke 1 dan 2 belum mengalami intensitas kerusakan, sedangkan untuk minggu ke 3,4,5,6,7 dan 8 secara berturut-turut yaitu $2 \%, 3 \%, 5 \%, 10 \%, 15 \%$ dan $16 \%$.

Berdasarkan analisis sidik ragam terlihat ada perbedaan nyata intensitas serangan hama $P$. Xylostella dan C. binotalis antara P3 ( $T$. subulata dan $T$. erecta) dengan P0 (kontrol) 
Tabel 2. Intensitas serangan P. xylostella dan $C$. binotalis pada kubis bunga

\begin{tabular}{lc}
\multicolumn{1}{c}{ Perlakuan } & Intensitas Serangan (\%) \\
\hline P0 : Kontrol & $0,80 \mathrm{bc}$ \\
P1: $T$. subulata & $0,76 \mathrm{ab}$ \\
P2: $T$. erecta & $0,75 \mathrm{ab}$ \\
P3: $T$. subulata + T. erecta & $0,73 \mathrm{a}$ \\
\hline
\end{tabular}

Keterangan: angka yang diikuti notasi yang sama pada kolom yang sama menunjukkan tidak berbeda nyata pada uji Duncan taraf $5 \%$

Intensitas serangan yang tinggi pada PO (Kontrol) yang merupakan penanaman tanaman kubis bunga yang ditanam secara monokultur atau tanpa tanaman refugia sehingga tidak adanya kestabilan ekosistem pada pertanaman. Tanaman refugia maka akan menjadi mikrohabitat bagi musuh alami selain itu berfungsi sebagai sumber pakan, inang alternatif untuk musuh alami sehingga ekosistem pertanaman menjadi lebih stabil (Septariani et al., 2019). Perlakuan P3 menunjukkan hasil yang relatif rendah dibandingan dengan perlakuan lainnya, hal tersebut karena kubis bunga yang ditanam dengan refugia $T$. subulata dan $C$. binotalis secara border crop yang dapat memberikan pengaruh terhadap keberadaan musuh alami (predator dan parasitoid) yang semakin banyak sehingga dapat meningkatkan keberagaman ekosistem dibandingkan dengan perlakuan tanpa menggunakan tanaman refugia P0 (kontrol). Penanaman tanaman border crop dapat berupa tanaman tanaman refugia yang dapat bersifat sebagai tempat berlindung bagi musuh alami dan sebagai tanaman repellant yang dapat menghasilkan aroma yang menyengat yang dapat menarik serangga (Farhat et al., 2010). Penanaman tanaman utama yang ditanam dengan tanaman pinggir akan dapat meningkatkan keragaman ekosistem sehingga dapat menurunkan populasi hama (Villanueva-López et al., 2019).

Penanaman tanaman secara monokultul dapat meningkatkan intensitas kerusakan yang tinggi karena populasi hama meningkatlntensitas kerusakan kubis bunga yang diakibatkan oleh hama pada perlakuan P3 lebih rendah dibandingkan dengan perlakuan P0, P1 dan P2. Hal tersebut disebabkan karena terdapat kombinasi antara kedua tanaman refugia yaitu $T$. subulate dan $T$. erecta. Rendahnya intensitas kerusakan hama tersebut karena refugia $T$. subulata mengandung senyawa seperti flavonoid, saponin, fenolik dan polifenol yang dapat menarik musuh alami atau bersifat antraktan (Mitchell et al., 2016; Sattler et al., 2020). Tanaman refugia $T$. erecta pada bagian daun dan bunganya mengandung senyawa alkaloid, flavonoid, tanin dan glikosida (Campera et al., 2021). T. Erecta memiliki potensi sebagai tanaman repellent pada beberapa hama sehingga dapat dijadikan sebagai tanaman pinggir. Tanaman refugia memiliki nektar dan polen yang dapat berfungsi sebagai sumber makanan bagi musuh alami (predator dan parasitoid).

\section{Persentase Parasitoid}

Tingkat parasitasi hama $P$. xylostella dan $C$. binotalis dapat diketahui dengan mengambil larva yang berada ditanaman kubis bunga kemudian dilakukan rearing untuk mendapatkan parasioidnya.

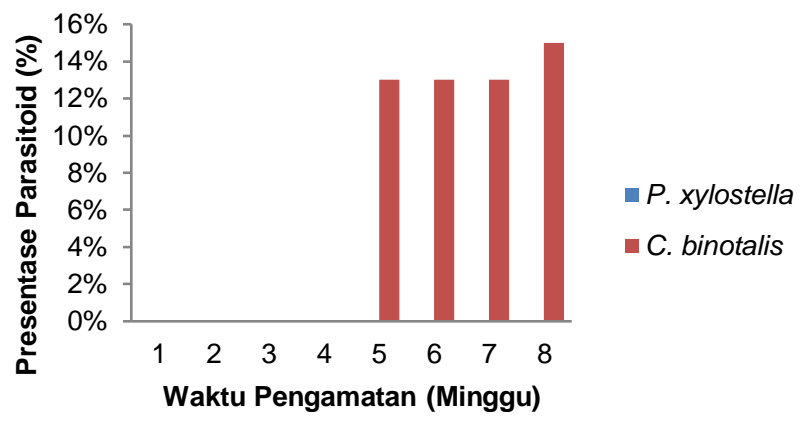

Gambar 5. Perbedaan Persentase Parasitoid $P$. xylostella dan C. binotalis

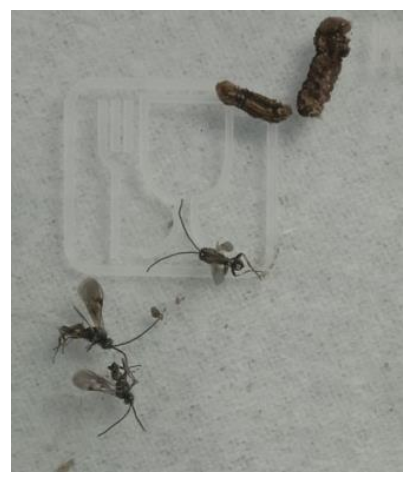

(a)

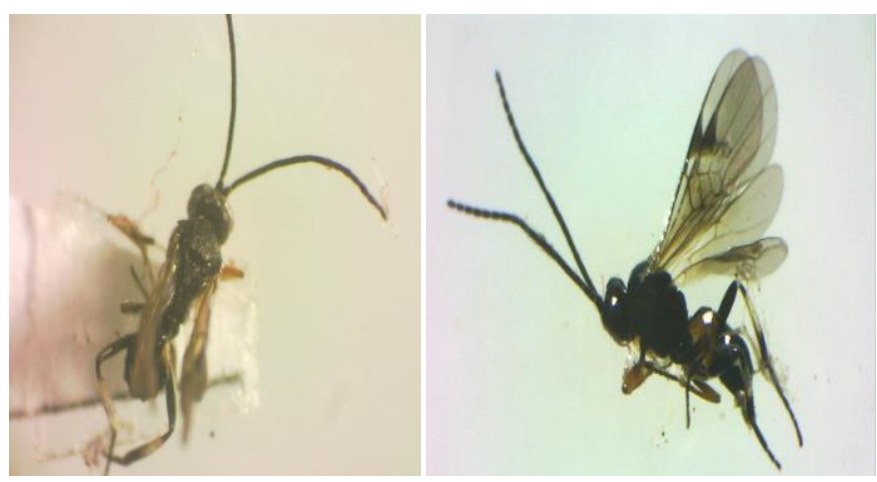

(b)

Gambar 6 (a) Parasitoid E. Argenteopilosus hasil rearing (b) Parasitoid E. Argenteopilosus hasil pengamatan dengan mikroskop dan optilap dengan perbesaran 1,5x

Berdasarkan Gambar 5, persentase parasitoid setiap minggu dari kedua hama tersebut berbeda beda. Parasitoid dari larva $P$. xylostella tidak ditemukan sama sekali pada setiap perlakuan. Persentase parasitoid untuk hama $C$. binotalis dari minggu ke 1-8 yaitu sebesar $15 \%$. Larva yang telah dilakukan rearing dan diamati beberapa minggu tidak ditemukan adanya parasitoid $D$. semiclausum. Larva dari hama $P$. xylostella menjadi pupa dan imago. Parasitoid dari hama $P$. xylostella tidak ditemukan hal tersebut dapat diakibatkan salah satunya karena jumlah populasi dari hama $P$. xylostella sedikit dilapangan. Hal tesebut terjadi karena tanaman kubis bunga yang ditanam pada saat penelitian dilakukan di daerah dataran yang kurang tinggi. Parasitoid $D$. 
semiclauasum yang merupakan parasitoid dari hama $P$. xylostella termasuk parasitoid yang paling banyak ditemukan didaerah dataran tinggi (Hakiki et al., 2015). Persentase parasitold dari hama $C$. binotalis dilahan pertanaman kubis bunga ditemukan hasil yang berbeda disetiap perlakuan. Parasitoid dari hama $P$. xylostella yaitu $D$. semiclausum tidak ditemukan sama sekali, sedangkan parasitoid dari hama $C$. binotalis yaitu $\mathrm{E}$. argenteopilosus dari minggu $1-8$ yaitu $15 \%$. Peningkatan kelimpahan musuh alami (predator dan parasitoid) kemungkinan dapat terjadi karena keanekaragaman tanaman yang lebih tinggi menyediakan sumber makanannya seperti nektar, serbuk sari, embun madu, dan lainnya serta habitat dan tempat berlindung yang baik untuk keberlangsungan musuh alami (Wan et al., 2018).

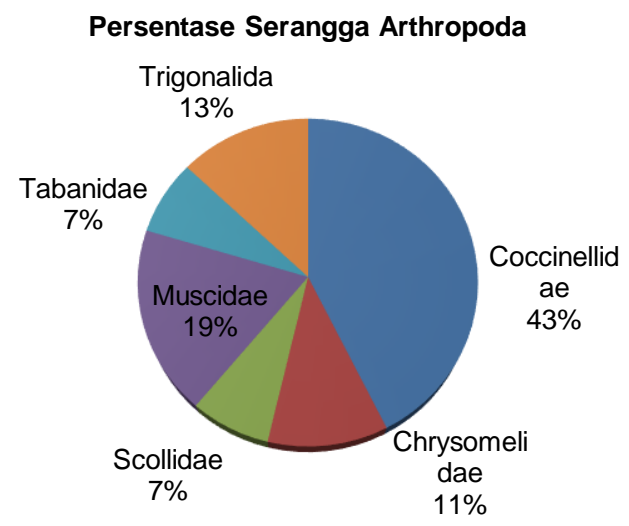

Gambar 7. Persentase Serangga Anthropoda

Jumlah kunjungan arhropoda pada lahan pertanaman kubis bunga menggunakan perangkap yellow pan trap, selain itu menggunakan alat perangkap lain yaitu vacuum untuk mengamati serangga yang terbang yang kecil yang kemudian disortasi berdasarkan ordo. Penggunaan yellow pan trap hanya digunakan untuk mengetahui kunjungan serangga yang datang di pertanaman kubis bunga. Pemilihan warna kuning karena warna dan kekontrasannya digunakan oleh serangga untuk membedakan antara tanaman inang dengan lingkungan sekitar. Adapun tujuan dan manfaat dari perangkap ini sebagai indikator populasi hama di area pertanaman atau keberadaan hama di sekitar tanaman, Serangga yang ditemukan di lapangan akan dilakukan identifikasi sampai tingkat famili, pada saat dilapangan pengamatan serangga terbang menggunakan alat beruavacum selain itu juga ada alat perangkap berupa yellow pan trap. Serangga yang ditemukan berdasarkan famili ada 8 yaitu dari famili Coccinelidae, Chrysomelidae, Scollidae, Tabanidae, Muscidae dan Trigonalidae. Famili yang paling banyak ditemukan yaitu dari Coccinelidae mencapai $23 \%$, famili Muscidae 10\%, famili Trigonalidae sebesar 7\%, famili Scollidae sebesar 4\%, famili Chrysomelidae 6\%, Tabanidae sebesar $4 \%$.

\section{KESIMPULAN}

Perlakuan border crop $T$. subulata dan $T$. erecta pada pertanaman kubis bunga efektif dalam menurunkan populasi hama dan itensitas serangan hama $P$. xylostella dan $C$. binotalis sehingga intensitas serangannya menurun. Parasitoid hanya ditemukan pada $C$. binotalis yakni $E$. argenteopilosus dengan tingkat parasitasi sebesar 15\%.

\section{DAFTAR PUSTAKA}

Amala, U., \& Shivalingaswamy, T. M. (2018). Effect of intercrops and border crops on the diversity of parasitoids and predators in agroecosystem. Egyptian Journal of Biological Pest Control, 28(1), 14. https://doi.org/10.1186/s41938-017-0015-y

Arif, A. (2015). Pengaruh bahan kimia terhadap penggunaan pestisida lingkungan. Jf Fik Uinam, $3(4)$, 134-143. http://103.55.216.56/index.php/jurnal_farmasi/articl e/view/2218

Badawy, G. M., Atallah, M. N., \& Sakr, S. A. (2019). Effect of gabapentin on fetal rat brain and its amelioration by ginger. Heliyon, 5(9), e02387. https://doi.org/10.1016/j.heliyon.2019.e02387

Badge, S., Panchbhai, D. M., \& Gajbhiye, R. P. (2015). Nutrient content, uptake and yield in African marigold (Tagetes erecta Linn) as influenced by pinching and foliar application of gibberellic acid. Indian Journal of Agricultural Research, 49(6), 534-538. https://doi.org/10.18805/ijare.v49i6.6681

Calumpang, S. M. F., \& Ohsawa, K. (2015). Repellency of marigold, Tagetes erecta L. (Asteraceae) volatile organic chemicals to eggplant fruit and shoot borer, Leucinodes orbonalis guenee (Lepidoptera: Crambidae). Journal of the International Society for Southeast Asian Agricultural Sciences, 21(2), 119128.

Campera, M., Balestri, M., Manson, S., Hedger, K., Ahmad, N., Adinda, E., Nijman, V., Budiadi, B., Imron, M. A., \& Nekaris, K. A. I. (2021). Shade trees and agrochemical use affect butterfly assemblages in coffee home gardens. Agriculture, Ecosystems and Environment, 319(November 2020), 107547. https://doi.org/10.1016/j.agee.2021.107547

Chandrasekara, A., \& Kumar, T. J. (2016). Roots and Tuber Crops as Functional Foods: A Review on Phytochemical Constituents and Their Potential Health Benefits. 2016.

Erdiansyah, I., Syarief, M., \& Taufika, R. (2021). Virulence of Spodoptera Litura Nuclear Polyhedrosis Virus ( SLNPV) with kaolin as carrier material on spodoptera litura and tetragonula laeviceps on soybean. IOP Conf. Series: Earth and Environmental Science, 672(012097). https://doi.org/10.1088/17551315/672/1/012097

Farhat, T., Ali, M. R., Niaz, M., Rahman, F., Kabir, M., \& Kochi, M. (2010). Effect of Border Crops on the Incidence of Insect Pests and Predators in Gram a Thesis Master of Science in Entomology. International Journal of Innovative Science, Engineering \& Technology, 1(10), 453-456.

Foster, B. J., Hereward, J. P., Uelese, A., Walter, G. H., \& Furlong, M. J. (2021). Trichogramma species in Samoa and their potential as biological control agents against the large cabbage moth, Crocidolomia pavonana. Biological Control, 164(October), 104781 . https://doi.org/10.1016/j.biocontrol.2021.104781 
Gogi, M. D., Syed, A. H., Atta, B., Sufyan, M., Arif, M. J., Arshad, M., Nawaz, A., Khan, M. A., Mukhtar, A., \& Liburd, O. E. (2021). Efficacy of biorational insecticides against Bemisia tabaci (Genn.) and their selectivity for its parasitoid Encarsia formosa Gahan on $\mathrm{Bt}$ cotton. Scientific Reports, 11(1), 1-12. https://doi.org/10.1038/s41598-021-81585-X

Hakiki, A., Karindah, S., \& Mudjiono, G. (2015). Jurusan Hama dan Penyakit Tumbuhan, Fakultas Pertanian, Universitas Brawijaya Jl. Veteran, Malang 65145. Jurnal HPT, 3(April), 91-99.

Heimoana, V., Pilkington, L. J., Raman, A., Mitchell, A., Nicol, H. I., Johnson, A. C., \& Gurr, G. M. (2017). Agriculture, Ecosystems and Environment Integrating spatially explicit molecular and ecological methods to explore the signi fi cance of non-crop vegetation to predators of brassica pests. "Agriculture, Ecosystems and Environment," 239, 12-19. https://doi.org/10.1016/j.agee.2017.01.008

Kamboj, N. K., Batra, V. K., Brar, N. S., Rana, M. K., \& Tanuj. (2017). Effect of various plant density at different levels of phosphorous and potash on growth and seed yield of onion (Allium cepa L.) cv. Hisar-2. Indian Journal of Agricultural Research, 51(5), 514-517. https://doi.org/10.18805/IJARe.A4749

Kristanto, S. P., Stjipto, \& Soekarto. (2013). Pengendalian Hama Pada Tnaman Kubis dengan Sistem Tanam Tumpangsari. Berkala IImiah Pertanian, 1(1), 7-9.

Li, J. Y., Chen, Y. T., Shi, M. Z., Li, J. W., Xu, R. Bin, Pozsgai, G., \& You, M. S. (2021). Spatio-temporal distribution patterns of Plutella xylostella (Lepidoptera: Plutellidae) in a fine-scale agricultural landscape based on geostatistical analysis. Scientific Reports, 11(1), 1-11. https://doi.org/10.1038/s41598-021-92562-9

Maina, S., Misinzo, G., Bakari, G., \& Kim, H. Y. (2020). Human, animal and plant health benefits of glucosinolates and strategies for enhanced bioactivity: A systematic review. Molecules, 25(16), 1-30. https://doi.org/10.3390/molecules25163682

Mitchell, C., Brennan, R. M., Graham, J., \& Karley, A. J. (2016). Plant Defense against Herbivorous Pests: Exploiting Resistance and Tolerance Traits for Sustainable Crop Protection. 7(July), 1-8. https://doi.org/10.3389/fpls.2016.01132

Mulyadi, H., Nasir, B., \& Yunus, M. (2017). PENGARUH KEMANGI DAN KENIKIR SEBAGAI TANAMAN REPELLENT TERHADAP Plutella xylostella Linn. (LEPIDOPTERA:PLUTELLIDAE) PADA BUDIDAYA SAWI ORGANIK. J. Agrotekbis, 5(5), 541-546.

Nazir, L. W. dan D. (2004). Teknologi pengendalian Hama Plutella xylostella dengan insektisida dan agensia Hayati pada Kubis di Kabupaten Karo. Jurnal Pengkajian Dan Pengembangan Teknologi Pertanian, 7, No.1, 27-34.

Nusra, M. S. F., Udukala, D. N., Amarasinghe, L. D., \& Paranagama, P. A. (2021). Volatiles from host plant brinjal attract the brinjal Fruit and Shoot Borer Leucinodes orbonalis Guenee. Journal of Asia-
Pacific Entomology, 24(3), 695-703. https://doi.org/10.1016/j.aspen.2021.06.002

Prabaningrum, L., \& Moekasan, T. (2017). Budidaya Kubis di Dalam Rumah Kasa Dalam Upaya Menekan Serangan Hama (Cultivation of Cabbage in the Netting House in Order to Reduce Pests Infestation). J. Hort, 27(1), 87-94.

Purwaningsih, R., Sartohadi, J., \& Anggri, M. (2020). Trees and crops arrangement in the agroforestry system based on slope units to control landslide reactivation on volcanic foot slopes in Java, Indonesia. Land, 9(9). https://doi.org/10.3390/LAND9090327

Rani, L., Thapa, K., Kanojia, N., Sharma, N., Singh, S., Grewal, A. S., Srivastav, A. L., \& Kaushal, J. (2021). An extensive review on the consequences of chemical pesticides on human health and environment. In Journal of Cleaner Production (Vol. 283). Elsevier Ltd. https://doi.org/10.1016/j.jclepro.2020.124657

Sattler, C., Gianuca, A. T., Schweiger, O., Franzén, M., \& Settele, J. (2020). Pesticides and land cover heterogeneity affect functional group and taxonomic diversity of arthropods in rice agroecosystems. Agriculture, Ecosystems and Environment, 297. https://doi.org/10.1016/j.agee.2020.106927

Sepe, M., \& Djafar, M. I. (2018). Perpaduan Tanaman Refugia Dan Tanaman Kubis Pada Berbagai Pola Tanam Dalam Menarik Predator Dan Parasitoid Dalam Penurunan Populasi Hama. AGROVITAL: Jurnal IImu Pertanian, 3(2), 55. https://doi.org/10.35329/agrovital.v3i2.206

Septariani, D. N., Herawati, A., \& Mujiyo, M. (2019). Pemanfaatan Berbagai Tanaman Refugia Sebagai Pengendali Hama Alami Pada Tanaman Cabai (Capsicum annum L.). PRIMA: Journal of Community Empowering and Services, 3(1), 1. https://doi.org/10.20961/prima.v3i1.36106

Setyadjit, \& Sukasih, E. (2015). Effect of Addition of Filler on the Production of Shallot (Allium Cepa Var. Ascalonicum L.) Powder with Drum Dryer. Procedia Food Science, 3, 396-408. https://doi.org/10.1016/j.profoo.2015.01.044

Villanueva-López, G., Lara-Pérez, L. A., Oros-Ortega, I., Ramírez-Barajas, P. J., Casanova-Lugo, F., RamosReyes, R., \& Aryal, D. R. (2019). Diversity of soil macro-arthropods correlates to the richness of plant species in traditional agroforestry systems in the humid tropics of Mexico. Agriculture, Ecosystems and Environment, 286(August), 106658. https://doi.org/10.1016/j.agee.2019.106658

Wan, N. F., Cai, Y. M., Shen, Y. J., Ji, X. Y., Wu, X. W., Zheng, X. R., Cheng, W., Li, J., Jiang, Y. P., Chen, X., Weiner, J., Jiang, J. X., Nie, M., Ju, R. T., Yuan, T., Tang, J. J., Tian, W. D., Zhang, H., \& Li, B. (2018). Increasing plant diversity with border crops reduces insecticide use and increases crop yield in urban agriculture. ELife, 7, 1-21. https://doi.org/10.7554/eLife.35103

Yuliantari, M., Widianarko, B., \& Sunoko, H. (2015). Analisis risiko pajanan pestisida terhadap kesehatan 
petani. Jurnal Kesehatan Masyarakat, 10(2), 239245.

Zulfikar, Z., Khairunnisa, K., \& Yasir, Y. (2019). Pengaruh Ekstrak Daun Bunga Tahi Ayam (Tagetes erecta) Terhadap Kematian Larva Aedes aegypti. Sel Jurnal Penelitian Kesehatan, 6(2), 66-73. https://doi.org/10.22435/sel.v6i2.2055 